\title{
ANTIOXIDANT ACTIVITY OF PLANT EXTRACTS FROM COLOMBIAN COFFEE-GROWING ECO-REGION
}

\section{ACTIVIDAD ANTIOXIDANTE DE EXTRACTOS VEGETALES DE LA ECO-REGIÓN CAFETERA COLOMBIANA}

\author{
Aura M. BLANDÓN', Oscar M. MOSQUERA ${ }^{\text {* }}$, Antônio E. G. SANT'ANA ${ }^{2}$, \\ Aldenir F. DOS SANTOS ${ }^{3}$, Luana L. S. PIRES ${ }^{2}$ \\ ${ }^{1}$ Grupo Biotecnología-Productos Naturales, Escuela de Química, Universidad Tecnológica \\ de Pereira. Carrera 27 No 10 - 02 Barrio Los Álamos. Pereira-Colombia. \\ ${ }^{2}$ Laboratorio de Pesquisa em Recursos Naturais, Instituto de Química y Biotecnología, \\ Universidade Federal de Alagoas. Cidade Universitaria, $\mathrm{Br}$ 101, km 14 norte, Tabuleiro dos \\ Martins Maceió, Alagoas - Brasil. \\ ${ }^{3}$ Departamento de Química, Universidade Estadual de Alagoas, Av. Governador Luís \\ Cavalcante, s/n, Alto do Cruzeiro. Arapiraca, Alagoas - Brasil.
}

*Autor Corresponsal. E-mail: omosquer@utp.edu.co
Historia del Artículo

Recibido: Julio 28, 2016 Evaluado: Enero 03, 2017 Aceptado: Enero 22, 2017 Disponible: Febrero 07, 2017

Abstract

The present study describes the in vitro antioxidant activity of methanol extracts of 34 plant species collected in the Colombian coffee-growing eco-region belonging to Euphorbiaceae, Piperaceae and Solanaceae families. The antioxidant properties of extracts were evaluated by determining radical scavenging power measured with a DPPH assay. The methanolic extracts of Hyeronimia antioquiensis, Mabea montana, and Alchornea grandis species (Euphorbiaceae), presents $\mathrm{EC}_{50}$ values equal to $0.686,12.35$, and 13.01 $\mu \mathrm{g} / \mathrm{mL}$, respectively, showing high antioxidant potential.

Keywords: Bioprospecting, DPPH, Euphorbiaceae, free radical, Piperaceae, Solanaceae.

\section{Resumen |}

El presente estudio describe la actividad antioxidante in vitro de 34 extractos metanólicos de especies vegetales recolectadas en la ecorregión cafetera colombiana (ECC) pertenecientes a las familias Euphorbiaceae, Piperaceae y Solanaceae. Las propiedades antioxidantes de los extractos fueron evaluadas a través de la determinación del poder captador de radicales con el ensayo de DPPH. Los extractos metanólicos de Hyeronimia antioquiensis, Mabea montana y Alchornea grandis presentaron $\mathrm{EC}_{50}$ iguales a $0,686,12,35$ y $13,01 \mu \mathrm{g} / \mathrm{mL}$, respectivamente, mostrando alto potencial antioxidante.

Palabras Clave: Bioprospección, DPPH, Euphorbiaceae, Piperaceae, Radical libre, Solanaceae.

\section{INTRODUCTION |}

Free radicals are atoms or groups of atoms having an unpaired electron; its high reactivity is due to the tendency to capture an electron from stable molecules to reach their electrochemical stability (Avello and Suwalsky, 2006). When the increase in intracellular free radicals content exceeds antioxidant defense the cell oxidative stress occurs, whereby damage to biomolecules such as lipids, proteins and nucleic acids is induced. Oxidative stress is involved in a wide variety of degenerative processes, diseases and syndromes such as cancer, atherosclerosis, Parkinson's disease, Alzheimer's disease and a variety of age-related changes (Boticario and Cascales, 2009).
The use of traditional medicine is widespread and plants are still a great source of natural antioxidants that can serve as potential sources for the development of new drugs (Parejo, 2003) that help to prevent oxidative damage that occurs in the body (Peng Wong, 2005).

In search of new sources of natural antioxidants and highlighting the importance of Colombian biodiversity, it was evaluated the antioxidant activity of 34 methanol extracts of some plant species collected in reserve areas of the departments of Caldas, Quindío and Risaralda that are part of Colombian Coffee-growing Eco-region (CCE) from Euphorbiaceae, Solanaceae and Piperaceae families. 


\section{MATERIALS AND METHODS}

\section{Chemicals}

2,2-Diphenyl-1-picrylhydrazyl radical $\left(\mathrm{DPPH}^{\bullet}\right)$ was provided from Sigma-Aldrich (Brasil). Hydroquinone was supplied from Sigma (USA). Methanol analytic grade was purchased from Vetec ${ }^{\circledR}$. A Gilson ${ }^{\circledR}$ multichannel pipette was used for serial dilutions and 96-well microplates for the assay was provided from TPP®. Thermo Scientific Multiskan Spectrum spectrophotometer was used for the bioassay.

\section{Plant materials and extraction}

The aerial part of the plants was collected at different sites of natural reserve of the departments of Caldas, Quindío and Risaralda. In Risaralda: Ucumarí Natural Regional Park [ $4^{\circ} 43^{\prime} 22.0^{\prime \prime} \mathrm{N}$ and $75^{\circ} 33^{\prime} 90^{\prime \prime} \mathrm{W}$ ], Alto El Nudo [ $4^{\circ} 52^{\prime} 35.4^{\prime \prime} \mathrm{N}$ and $\left.75^{\circ} 42^{\prime} 53.5^{\prime \prime} \mathrm{W}\right]$, La Nona and La Marcada [4 $4^{\circ} 53^{\prime} 53.1^{\prime \prime} \mathrm{N}$ and $75^{\circ} 43^{\prime} 21.9^{\prime \prime} \mathrm{W}$ ]. In Caldas: Los Yarumos Park [5 $04^{\prime} 23.9^{\prime \prime} \mathrm{N}$ and $\left.75^{\circ} 29^{\prime} 11.7^{\prime \prime} \mathrm{W}\right]$. In Quindio: Protected area Bremen-La Popa [ $4^{\circ} 40^{\prime} 40.0^{\prime \prime} \mathrm{N}$ and $\left.75^{\circ} 37^{\prime} 15^{\prime \prime} \mathrm{W}\right]$. Species were identified by the taxonomist Francisco Javier Roldan from the Herbarium of the University of Antioquia where each specimen voucher numbers are kept (Table 1).

Then, the aerial part of plants was dried in oven at $50{ }^{\circ} \mathrm{C}$, macerated and extracted with methanol by passive maceration with subsequent rotary evaporation of the solvent; the extract obtained were kept refrigerated until use.

\section{Antioxidant activity}

The methodology of antioxidant activity assay of plant extracts was based on Brand-Williams, et al., (1995) and Mensor, et al., (2001) with some modifications.

A solution of $0.3 \mathrm{mM}$ DPPH in methanol was prepared in amber flask, covering with aluminum foil immediately after solution preparation, cooled to $4^{\circ} \mathrm{C}$ between each trial and each day of analysis a different solution was prepared.

Sample stock solutions $(1.0 \mu \mathrm{g} / \mathrm{mL})$ were diluted to final concentrations of 500, 250, 125, 62.5, 31.25, 15.625 and 7.8125 $\mu \mathrm{g} / \mathrm{mL}$ in a 96 -well microplate with methanol. $40 \mu \mathrm{L}$ of a solution of $0.3 \mu \mathrm{M}$ DPPH was added to $100 \mu \mathrm{L}$ of the extract solutions at different concentrations and allowed to react in complete darkness for 30 minutes at room temperature.

The absorbance was measured at $518 \mathrm{~nm}$ using a microplate spectrometer Thermo Scientific Multiskan ${ }^{\circledR}$ Spectrum and was converted to percentage of antioxidant activity according to the following expression (Mensor, et al, 2001):

$$
\% A A=100-\frac{\left(A b s_{\text {sample }}-A b s_{\text {blank }}\right) \times 100}{A b s_{\text {control }}}
$$

Methanol $(100 \mu \mathrm{L})$ plus plant extract solution $(100 \mu \mathrm{L})$ was used as a blank. DPPH solution ( $40 \mu \mathrm{L} ; 0.3 \mathrm{mM})$ plus ethanol $(100 \mu \mathrm{L})$ was used as a negative control. As a positive control hydroquinone was used $(1000 \mu \mathrm{g} / \mathrm{mL})$. Assays were performed in triplicate. The half maximal effective concentration $\left(\mathrm{EC}_{50}\right)$ values were calculated by non-linear regression of plots where the abscissa represented the concentration of tested plant extracts and the ordinate the average percent of antioxidant activity

\section{Statistical analysis}

Nonparametric Kruskal-Wallis test was performed at a significance level of 0.05 for each family extracts according to the percentage of antioxidant activity at the highest concentration. As well as, the same test was performed by comparing the percentage of antioxidant results for each of the seven concentrations of extract tested activity. The statistical package Graph-Pad Prism 5.0 for Windows ${ }^{\circledR}$ was used.

\section{RESULTS AND DISCUSSION}

Study results of antioxidant activity as a percentage of the antioxidant activity (\% $\mathrm{AA}$ ) extract at 500 and $\mathrm{EC}_{50}$ values for each sample are presented in Table 1.

Recently, the DPPH assay has become very popular in the studies of natural antioxidants, because the method is simple and highly sensitive (Moon and Shibamoto, 2009), also proved to be independent of the polarity of the substrate (Koleva et al. 2002). The assay is based on the theory that a hydrogen atom donor is an antioxidant and this effect is proportional to the disappearance of the purple color of DPPH (Moon and Shibamoto, 2009).

Species from genus Piper are commonly used in traditional medicine for their antioxidant properties (Khalaf et al., 2008). In this study, extracts from P. pesaresanum and $P$. daniel-gonzalezii at $500 \mu \mathrm{g} / \mathrm{mL}$ showed $100 \%$ of antioxidant activity and most of Piper extracts showed important radical scavenging ability. Methanolic extracts from $P$. bettle, $P$. betleiodes and $P$. wallichii from North East India also showed scavenging ability on DPPH radicals with $\mathrm{EC}_{50}$ values 41.7 , 55.4, and $67.4 \mu \mathrm{g} / \mathrm{mL}$, respectively (Tamuly, et. al. 2013). Methanolic extracts from $P$. guineense, $P$. nigrum $L$. and $P$. umbellatum L. showed 79.8-89.9\% scavenging ability on DPPH (Agbor et al., 2007). In general, the content of flavonoids and phenols in species from genus Piper had been related to the antioxidant properties.

The antioxidant potential of plant extracts is inversely correlated to $\mathrm{EC}_{50}$. Some species from Euphorbiaceae family studied shows the lowest $\mathrm{EC}_{50}$ value, namely: Hyeronima antioquiensis ( $0.686 \mu \mathrm{g} / \mathrm{mL})$, Mabea montana $(12.35 \mu \mathrm{g} / \mathrm{mL})$, and Alchornea grandis $(13.01 \mu \mathrm{g} / \mathrm{mL})$. Studies about antioxidant properties of Jatropha gossypiifolia demonstrated significant radical scavenging ability by DPPH assay $\left(I C_{50}=1.205 \mu \mathrm{g} / \mu \mathrm{L}\right)$, this antioxidant activity was attributed to the flavonoids content (Félix-Silva et. al. 2014). Butanol extract from Ricinus communis was also evaluated by 
DPPH assay in Pakistan obtaining $83.1 \%$ scavenging activity and $I C_{50}=65,1 \mu \mathrm{g} / \mathrm{mL}$ correlated with a high total phenol content (Shahwar, et.al., 2010).

Table 1. Percentage of antioxidant activity at $500 \mu \mathrm{g} / \mathrm{mL}$ and EC50 of methanolic plant extracts.

\begin{tabular}{|c|c|c|c|}
\hline Family & Specie (Code) & $\begin{array}{c}\% A A \text { at } \\
500 \mu \mathrm{g} / \mathrm{mL}\end{array}$ & $\begin{array}{c}E_{50} \\
(\mu \mathrm{g} / \mathrm{mL})\end{array}$ \\
\hline \multirow{8}{*}{ Euphorbiaceae } & Acalypha macrostachya (FJR 4050) & $82.43 \pm 1.81$ & 104.3 \\
\hline & Alchornea sp (FJR 3982) & $87.10 \pm 7.44$ & 30.67 \\
\hline & Alchornea grandis (FJR 4056) & $87.82 \pm 3.58$ & 13.01 \\
\hline & Acalypha diversifolia (FJR 3967) & $97.63 \pm 2.09$ & NC \\
\hline & Alchornea calophylla (FJR 3969) & $94.35 \pm 2.10$ & NC \\
\hline & Hyeronima antioquiensis (FJR 3905) & $92.25 \pm 3.35$ & 0.686 \\
\hline & Mabea montana (FJR 3912) & $95.25 \pm 1.27$ & 12.35 \\
\hline & Hyeronima sp (FJR 3971) & $96.59 \pm 0.56$ & 66.59 \\
\hline \multirow{9}{*}{ Piperaceae } & Piper pesaresanum (FJR 3996) & $100.0 \pm 9.97$ & NC \\
\hline & Piper daniel-gonzalezii (FJR 4051) & $100.0 \pm 12.8$ & 49.48 \\
\hline & Piper glanduligerum (FJR 4026) & $81.54 \pm 5.79$ & 191.4 \\
\hline & Piper crassinervium (FJR 4021) & $90.76 \pm 3.17$ & 61.62 \\
\hline & Piper umbellatum (FJR 4012) & $59.64 \pm 3.98$ & NC \\
\hline & Piper crassinervium (FJR 4030) & $84.39 \pm 4.53$ & 72.59 \\
\hline & Peperomia acuminata (FJR 4002) & $93.75 \pm 3.76$ & NC \\
\hline & Piper eriopodon (FJR 4007) & $92.70 \pm 1.36$ & 43.29 \\
\hline & Piper calceolarium (FJR 4048) & $79.92 \pm 1.75$ & 141.3 \\
\hline \multirow{17}{*}{ Solanaceae } & Solanum acerifolium (FJR 3961) & $74.72 \pm 5.75$ & 106.8 \\
\hline & Solanum cf umbellatum (FJR 3962) & $92.50 \pm 1.55$ & 143.4 \\
\hline & Dunalia solanacea (FJR 3992) & $48.33 \pm 1.87$ & 283.2 \\
\hline & Solanum ovalifolium (FJR 4027) & $95.09 \pm 0.56$ & 105.7 \\
\hline & Cestrum sp (FJR 3978) & $70.07 \pm 14.8$ & 92.59 \\
\hline & Browallia speciosa (FJR 4025) & $64.34 \pm 0.72$ & 699.2 \\
\hline & Deprea aff sachapapa (FJR 4024) & $0.00 \pm 11.4$ & 231.3 \\
\hline & Solanum brevifolium (FJR 4028) & $46.27 \pm 2.26$ & 1522 \\
\hline & Solanum sp (FJR 3970) & $87.61 \pm 3.59$ & 137.9 \\
\hline & Witheringia coccoloboides (FJR 4019) & $84.75 \pm 7.93$ & 343.2 \\
\hline & Solanum trachycyphum (FJR 4042) & $20.25 \pm 3.22$ & 396.2 \\
\hline & Solanum sp (FJR 4010) & $87.15 \pm 5.60$ & 267.7 \\
\hline & Solandra coriacea (FJR 4013) & $71.28 \pm 3.23$ & 277.1 \\
\hline & Cestrum humboldtii (FJR 4022) & $15.12 \pm 13.6$ & NC \\
\hline & Solanum lepidotum (FJR 3975) & $76.69 \pm 2.23$ & 330.4 \\
\hline & Lycianthes radiata (FJR 3993) & $100.0 \pm 11.7$ & 1403 \\
\hline & Solanum sp (FJR 4043) & $90.93 \pm 1.92$ & 468.5 \\
\hline \multicolumn{2}{|c|}{ Hydroquinone $(1000 \mu \mathrm{g} / \mathrm{mL})$} & $50,08 \pm 1,04$ & NC \\
\hline
\end{tabular}

NC: Not calculated.

As Mosquera et al., (2007) previously demonstrated, species of the Euphorbiaceae family, in particular of the genus Acalypha, have a high antioxidant potential, with percentages of antioxidant activity above $50 \%$ at $250 \mathrm{mg} / \mathrm{L}$ as assessed by DPPH method. Other study proved that the methanol extract of Acalypha fruticosa have strong antioxidant activity, comparable to the activity presented by butylated hydroxytoluene (BHT) used as a control; the authors attributed this activity to the high flavonoids content (Thambiraj et al., 2012).
In the present study, the genus Alchornea also showed strong antioxidant activity: Alchornea sp. $\left(E_{50}=30.67 \mu \mathrm{g} / \mathrm{mL}\right)$, A. grandis $\left(E C_{50}=13.01 \mu \mathrm{g} / \mathrm{mL}\right)$, and $A$. calophylla showed antioxidant activity percentages above $90 \%$. Kouakou-Siransy et al., 2010 reported that the aqueous extract of the species A. cordifola presented significant antioxidant activity with $\mathrm{IC}_{50}=6.5 \mathrm{mg} / \mathrm{L}$, correlated to a high flavonoids content.

Many species from Solanaceae family are used by its medicinal properties around the world. Our study includes 17 species from different genus and a variety of results. The highest percentage of antioxidant activity was showed by $L$. radiata, S. ovalifolium, and S. cf umbellatum (100, 95.09, and $92.50 \%$, respectively). Al-Fatimi et al., 2007 reported that methanol extract from Solanum nigrum presented antioxidant properties with $94.5 \%$ of antioxidant activity at $500 \mu \mathrm{g} / \mathrm{ml}$. Studies about some Solanaceae species from India suggested that the extract form Solanum anguivi is a promising natural source of antioxidants (Gandhiappan et al., 2012).

In conclusion, this study showed that Colombian coffeegrowing eco-region is a great source of promissory plant species by the presence of antioxidant compounds responsible for their radical scavenging ability; in particular, Hyeronimia antioquiensis (Euphorbiaceae) showed the lowest $\mathrm{EC}_{50}$ value $(0.69 \mu \mathrm{g} / \mathrm{mL})$. Further studies focused on the elucidation of chemical constituents of the promising extracts are highly required, as well as in vivo assays are important for the characterization of the extracts as biological antioxidants.

\section{ACKNOWLEDGMENT|}

Authors thank Technological University of Pereira and its Office of International Relations, the research group in biotechnology and natural products at Technological University of Pereira and research in natural resources laboratory (LPqRN) at Federal University of Alagoas.

\section{CONFLICT OF INTEREST}

All authors have none to declare.

\section{REFERENCES}

- Al-Fatimi, M., Wurster, M., Schröder, G., Lindequist, U., 2007. Antioxidant, antimicrobial and cytotoxic activities of selected medicinal plants from Yemen. Journal of Ethnopharmacology, 111(3): 657-666.

- Agbor, G.A., Vinson, J.A., Oben, J.E., Ngogang, J.Y., 2007. In vitro antioxidant activity of three Piper species. Journal of Herbal Pharmacotherapy, 7, 49-64.

- Avello, M., Suwalsky, M., 2006. Radicales libres, antioxidantes naturales y mecanismos de protección. Atenea (Concep.), 494, 161-172.

- Brand-Williams, W., Cuvelier, M. E., Berset, C., 1995. Use of a Free Radical Method to Evaluate Antioxidant Activity. Lebensmittel-Wissenschaft \& Technologie, 28, 25-30

- Boticario, C., Cascales, M., 2009. Innovaciones en Cáncer. Madrid: UNED.

- Félix-Silva, J., Souza, T., Camara, R.B.B.G., Cabral, B., Silva-Júnior, A.A., Rebecchi, I.M.M., Zucolotto, S.M., Rocha, H.A.O., Fernandes-Pedrosa, M.d.F., 2014. In vitro anticoagulant and antioxidant activities of Jatropha gossypiifolia L. (Euphorbiaceae) leaves aiming therapeutical applications. BMC Complementary and Alternative Medicine, 14, 405. 
- Gandhiappan, J., Rengasamy, R., 2012. Comparative study on antioxidant activity of different species of Solanaceae family. Advances in Applied Science Research, 3(3), 1538-1544.

- Khalaf, N. A., Shakya, A. K., Al-Othman, A., El-Agbar, Z., Farah, H., 2008. Antioxidant activity of some common plants. Turkish Journal of Biology, 32(1): 51-55.

- Koleva, I. I., van Beek, T. A., Linssen, J. P. H., Groot, A. d., Evstatieva, L. N., 2002. Screening of Plant Extracts for Antioxidant Activity: a Comparative Study on Three Testing Methods. Phytochemical Analysis 13(1): 8-17.

- Kouakou-Siransy, G., Sahpaz, S., Nguessan, G., Datté, J. Y., Brou, J. K., Gressier, B., Bailleul, F., 2010. Effects of Alchornea cordifolia on elastase and superoxide anion produced by human neutrophils. Pharmaceutical Biology 48(2), 128-133.

- Mensor, L. L., Menezes, F. b. S., Leitão, G. G., Reis, A. S., Santos, T. C. d., Coube, C. S., Leitão, S. G.,2001. Screening of Brazilian plant extracts for antioxidant activity by the use of DPPH free radical method. Phytotherapy Research 15(2): 127-130.

- Moon, J.K., Shibamoto, T., 2009. Antioxidant Assays for Plant and Food Components. Journal of Agricultural and Food Chemistry, 57(5): 1655-1666.

- Mosquera, O. M., Correa, Y. M., Buitrago, D. C., Niño, J., 2007. Antioxidant activity of twenty five plants from Colombian biodiversity. Memórias do Instituto Oswaldo Cruz, 102(5): 631-634.
- Parejo, I., Viladomat, F., Bastida, J., Rosas-Romero, A., Saavedra, G., Murcia, M. A., Jiménez, A. M., Codina, C., 2003. Investigation of Bolivian plant extracts for their radical scavenging activity and antioxidant activity. Life Science, 73(13), 1667-1681.

- Shahwar, D., Shafiq-ur-Rehman, Ahmad, N., Ullah, S., Raza, M.A., 2010 Antioxidant activities of the selected plants from the family Euphorbiaceae, Lauraceae, Malvaceae and Balsaminaceae. African Journal of Biotechnology, 9(7), 1086-1096.

- Tamuly, C., Hazarika, M., Bora, J., Bordoloi, M., Boruah, M. P., Gajurel, P. R. In vitro study on antioxidant activity and phenolic content of three Piper species from North East India, 2013. Journal of Food Science and Technology, 52(1), 117-128.

- Thambiraj, J., Paulsamy, S., Sevukaperumal, R., 2012. Evaluation of in vitro antioxidant activity in the traditional medicinal shrub of western districts of Tamilnadu, India, Acalypha fruticosa Forssk. (Euphorbiaceae). Asian Pacific Journal of Tropical Biomedicine, S127-S130.

- Wong, S., Leong, L., Williamkoh, J., 2006. Antioxidant activities of aqueous extracts of selected plants. Food Chemistry. 99(4), 775-783. 